\section{Gondolatok egy idôszociológiai vizsgálathoz}

Tôszegénység, modem időzavar, felgyorsult élettempó, mind olyan fogalmak, 1 melyeket a modem társadalomban történt változások hívtak életre. Vészesen aktuálissá vált az eddig mostohagyermekként kezelt időkezelés, időorientáció, „idõfogyasztás” körültekintő, alapos és szakszerũ vizsgálata. Az utóbbi évtizedek kutatási eredményei hívják fel a figyelmet a (szubjektív)idô-viszonyulás mentális és testi egészségre, tanulmányi előmenetelre, fogyasztásta gyakorolt szignifikáns hatásáta - és a sort még folytathatnánk (lásd pl. Kasser 2006; Meleg 2006; Tahin-Jeges-Lampek 2000; Török 2006a; Török 2006b).

Társadalmunkban elterjedt vélemény, hogy a fiatalok körében az uralkodó nézet egyfajta carpe diem szemlélet, mely természetesen meghatározza ezen korcsoport jelenhez és jövőhöz való viszonyát is. A témában zajló kutatások egyik legnagyobb hiányosságának azt tartom, hogy a jövőorientáció legfontosabb indikátorának a foglalkozási és iskolai mobilitást tartják, ti. azon egyének tekinthetők jövőorientáltnak, akinek tanulmányi pályája felfelé haladó lineáris utat fut be, illetve munkaerôpiaci pozíciójára is ez a felfelé történố mozgás jellemző.

Kutatásomban egy olyan tabula rasat akartam kezdeni, mely nem határolja be a vizsgálódás irányát, konkrét tárgyát, lehetőséget biztosítva így arra, hogy a kutatási téma úgyszólván önmagát bontsa ki. Arra voltam kíváncsi, hogy általánosságban az idővel, annak észlelésével kapcsolatban milyen problémás területek bontakoznak ki. Ennek érdekében a legcélravezetóbb kutatási módszernek a mélyinterjú technikáját találtam, melynek keretében az interjúalanyok nem egy elvárt struktúra, hanem saját mentális struktúrájuk szerint építhetik fel a témával kapcsolatos gondolataikat. A beszélgetést csupán egy az interjús beszélgetés folyamatosságát biztosító interjúvázlat strukturálta, teret hagyva az interjúalanyok számára, hogy véleményüket szabadon kifejthessék.

Módszertanilag a megalapozott elmélet talaján álló kutatásomtól azt várom, hogy az induktív módon nyert adatok nagy érvényességgel alkalmazhatók legyenek a valóságra. Kutatásommal nem titkolt szándékom olyan problémafelvetés körvonalazása, mely a későbbiekben kutatói kérdésekké, hipotézisekké fordítható le (lásd bővebben Kucsera 2008).

A kutatás során 2009. január és február között 17 mélyinterjút vettünk fel 15-17 éves középiskolás diákokkal1'. Az interjúban arra kértük a diákokat, hogy az élettörténetükön túl meséljenek a napjaikról, az általuk végzett tevékenységekről, szabadidős elfoglaltságaikról, vágyaikról, céljaikról. Az interjú zárásaként jelenlegi élethelyzetükre, időfelhasználásukra, időbeosztásukra kellett reflektálniuk (pl. elégedettség, kontrollérzés stb.).
Ahogyan a bevezetôben is említettem, a kutatás céljai között nem szerepel számszerũsíthetô adatok kiszũrése. Feltáró érdeklődésem homlokterében az áll, hogy az interjúalanyok hogyan irányítják a beszélgetést, milyen jellegzetes témaköröket említenek, melyek azok a fô elemek, amelyek strukturálják a beszélgetést (természetesen a megadott keretek között). Reményeim szerint a beszélgetések olyan ismeretekkel szolgálhatnak, melyek kiindulópontját jelenthetik későbbi, más strukturált kutatásnak. Célom, hogy az interjúkban megbúvó látens struktúrák kitapinthatóvá váljanak.

Mélyinterjút 17 középiskolás diákkal készítettünk, közülük 12 lány és 5 fiú.

Érdemes górcső alá venni az interjúalanyok által végzett tevékenységeket, melyek az idố hordozói. Az említett tevékenységek száma szerint az alanyokat két csoportra lehet osztani. Egyesck napjait igen töredezetté teszi a végzett tevékenységek sora, míg mások időfolyamát alig szakítják meg a különböző tevékenységek. A tevékenységek jellegét tekintve minden alany esetében kötelezô és választható/választott tevékenységekrōl beszélhetünk. A kötelező tevékenységek minden esetben az iskolával és/vagy tanulással kapcsolatosak, ide sorolva pl. a magánórákat vagy a korrepetálást és fakultációt. Tipikusnak tekinthetô vélemények:

$$
\begin{gathered}
\text { "Srabadidönek ąt az idöt tekintem, amin nem tanulok..." } \\
-15 \text { éves fiú - }
\end{gathered}
$$

\section{„A tanulás az keell, az muszajj!”}

$$
16 \text { éves lány - }
$$

A tanulás mindennapi tevékenység, mely értelemszerũen szervesen épül be a diákok idõrendjébe, mint ahogy az egyéb kötelezõ tevékenységek is. Szubjektív értelemben ezek a kötelezổ tevékenységek kontrollálhatatlanok, külső kényszerítổ erôvel hatnak az ember életére. Ez természetesen nem jelent automatikusan negatív hozzáállást is, csupán annyit, hogy a megkétdezettek kivétel nélkül olyan időintervallumként jelölik meg, melyre semmilyen hatással nem lehetnek. Az természetesen már egyénenként változik, hogy érzelmileg hogyan viszonyulnak ehhez az időszakhoz.

Tagadhatatlan azonban, hogy a megkérdezettek fontos szerepet tulajdonitanak a tanulásnak, tevékenységeik közül talán ezt itélik a legfontosabbnak. Ezen nem módosít az sem, hogy ezen elkötelezettség az egyén belülről fakadó kötelezettsége, avagy külső hatás eredménye (pl. szülöi ösztönzés, sőt nem ritkán kontroll eredménye).

$\mathrm{Az}$ interjút adók között elenyészõ azok aránya, akik nem rendelkeznek valamilyen formán kidolgozott jövőképpel, azonban többnyire határozott elképzeléssel rendelkeznek a jövôt illetõen, igaz más-más területen. Van, akinek jövö- 
képében a tanulás foglal el kitüntetett szerepet, van, akinek a munkavállalás. Jelenlegi élethelyzetüket, cselekedeteiket tehát befolyásolja jövőbeni várakozásuk. A jövổ befolyásoló hatása azonban nem mindenkinél érvényesül egyformán. Kétféle magatartás, attitũd figyelhetô meg. van, aki inkább sodródik a jövô felé, és van, aki tudatosan halad jövôbeni céljai irányába. Ez a kétfajta attitũd azonban nem határolható el élesen egymástól, ti. mindannyian tudatában vannak jelen és jövő egymásra hatásának.

Általánosságban elmondható, hogy a tanulással töltött idổ nem része a fiatalok „időszámításának”, egy olyan időintervallumról van szó, mely adott, befolyásolhatatlan, kontrollálhatatlan, így egy tỏlük független létezô. A tanulásta forditott idỏ negatív hatásáról azonban már számos esetben említést tesznek, negatív visszaható erejét naponta érzik. $\mathrm{Ez}$ az az idổ ugyanis, ami minden más tevékenységre ('́gy időre is) hatással van. Gyakran említik a diákok, hogy a tanulásra fordított idổmennyiség miatt nem jut más tevékenységekte idejük.

\section{„Gyakran megfordul a fejemben, hogy a tanulásra sincs idöm."}

$$
16 \text { éves lány - }
$$

Extrém esetekben az iskolában töltött időn kívüli időszak meghatározó tevékenységei is mind az iskolához, tanuláshoz köthetôk. Volt olyan interjúalany, aki elmondása szerint a hétköznapokon iskolán kívül sem foglalkozik mással csak a tanulással, az egyes tanórákra való felkészüléssel. Ezek a diákok azonban nem a legjobban teljesítők köréből rekrutálódnak, az okok véleményem szerint nem a jobb teljesítmény elérése mögött meghúzódó motivációkban keresendők kizárólag, hanem időkezelési hiányosságok is meghúzódhatnak mögötte. Vannak ugyanis olyan interjúalanyok, akik iskolán kívüli idejét számtalan tevékenység szabdalja, mégsem romlik iskolai teljesítményük, és nem panaszkodnak az idô szoritásáról.

Külön csoportként kezelendô azon tevékenységek köre, melyek habát jellegüknél fogva szabadon válaszhatók, mégis felveszik a kötelezỏ tevékenységek egyes jellemezőit. Ide sorolhatjuk az olyan tevékenységeket, melyek a múlt „maradványai": jellemzỏen gyermekkorban elkezdett tevékenységek, amelyek vagy szülöi hatásra elkezdett vagy önként végzett tevékenységek (általában sporttevékenységek vagy zeneóra). Ami azonban hasonlatossá teszi a kötelezô tevékenységekhez az az, hogy a tanuláshoz hasonlóan a mindennapok szerves része, mely valamikor önként vállalt tevékenység ma kényszerítôen hat az egyénre. Kissé a megszokás uralja ezen tevékenységi kört.

Nem lebecsülve a fent bemutatott ún. kötelezõ/kvázi-kötelezõ tevékenységek jelentőségét, a szabadidőben végzett tevékenységek vizsgálata nagyobb kihívást jelent. Számszerũen is több tevékenység tartozik ebbe a körbe, jellegüket tekintve is igen változatosak. Ezen kívül a szabadon választott tevékenységek idővonatkozása egészen más attitüdöt kíván meg, rejt magában, ennél fogva pedig újabb kérdéses pontokra mutatnak rá. Ez az a tevékenységi kör és idỏ- szak, melyek az egyéni döntés körébe tartoznak, így jól megfigyelhetõ az egyéni időszemlélet és idôkezelés. A legváltozatosabb tevékenységek alkotják ezen kört, úgy mint pl. barátokkal történô találkozás, sportolás, internetezés, olvasás, családi programok, sütés-fôzzés, és a sort még lehetne folytatni. Ebbe a körbe kell sorolni azt az idốt, melyet az emberek úgymond passzívan töltenek el (pl zenehallgatás, tévénézés).

Erre a tevékenységcsoportra nagyfokú autonómia és kontroll jellemzô. Az alanyok kivétel nélkül arról számolnak be, hogy a szabadidejük eltöltési módja, mikéntje és nem utolsó sorban mennyisége felett kizárólag ők rendelkeznek. Egyesek azonban megemlitik, hogy a barátaik, szüleik azért némi hatással van nak a szabadidôre, ugyanis számtalan olyan tevékenység tartozik ebbe a csoportba, mely csoportos tevékenység, így a csoporttagok idejének összehangolása szükségeltetik.

A szabadon választott tevékenységekre jutó idő nagy szóródást mutat. Azok az interjúalanyok, akik meglehetősen sok időt forditanak tanulásra, arról számoltak be, hogy időszűke miatt nem tudnak más tevékenységre is időt fordítani.

\section{"Igazából a szabadidômre marad elég kevés idô, mert a tanulásra kell koncentrálnom."}

$$
16 \text { éves lány - }
$$

A skála másik végén azon egyének foglalnak helyet, akik elmondásuk szerint minimális idôt töltenek tanulással, kötelezõ tevékenységekkel. Ezek az egyének nem ritkán az iskolaidôn kívül már nem foglalkoznak a tanulással.

„Vagy itthon vagyok és számitógépezek, játszok vagy internetezek, vagy a baverokekal elmegyünk valamerre, vagy lemegyünk valamelyik haverhoz, ątán pókerezünk, vagy csak ügy lógunk valahol."

"Megpróbálunk minél bosszabban együtt lenni, bogy el tudjuk sqórakozni az idöt."

$$
17 \text { éves fiú - }
$$

Az interjúalanyok nagy része esetében a hétköznapokat és a hétvégéket egyaránt számos nem kötelezô jellegũ tevékenység teszi ki. Fontos megkülönböztetni a szabadon választott tevékenységek esetében az aktív és passziv cselekvéseket. Jelen esetben aktív cselekvésnek nevezem a különbözó sporttevékenységeket, baráti találkozókat, családi progtamokat, stb.; passzív tevékenységnek pedig az olvasást, tévénézést, zenehallgatást stb. tekintem. Fontosnak tartom ezen megkülönböztetést tenni, mivel az interjúalanyok nagy részére inkább az aktív tevékenységek végzése a jellemzó, míg másik részük iskolán kívüli idejüket inkább passzivan élik meg.

\section{„A bétföt kivéve minden nap van különórám, beti 4 edzés és 2 rajzóra."} 16 éves lány - 
Az idôfelhasználás szempontjából van jelentôsége a különbségtételnek; az időérzékelés, időkezelés, egyáltalán az időhöz való hozzáállás szoros összefüggést mutat ezekkel a tevékenységekkel. Azok az egyének ugyanis, akik számos aktí tevékenységet végeznek, tákényszerülnek idejük kontrollálására, arra, hogy ha tékonyan osszák be idejüket. A passziv tevékenységek ugyanezt a képességet nem követelik meg, nem kívánják meg a racionális időbeosztást. Az látható hogy a sokféle tevékenység mellet is marad az egyéneknek olyan „ráérôideje”, mely a passzív tevékenységek időtere. Azoknak a tanulóknak, akik szükölködnek a szabadon választható tevékenységekben (mely rendszerint önként vállalt „életforma”), szabadidejük nagy része „ráérőidő”, mely intervallumban egy cél van csak: elütni az idôt. Nem egyedi eset, hogy ezek az emberek arról panaszkodnak, hogy kifolyik kezükből az idô, nehezen tudják kontrollálni azt.

„A bétkëznapi idöfelhasználásommal nem vagyoke elégedett, ąt valabogyan jobban ki kéne tölteni, mert az esti órák elég lassan telnek és unalmasak. Nem mindig tudunk olyan elszórakozni, hanem csak úgy unatkorunk esténként."

$$
-16 \text { éves fiu - }
$$

Velük szemben azonban vannak olyan feszitett napirenddel tendelkezők, akik oly mértékben uralják időbeosztásukat, hogy gond nélkül tudják az egyes tevékenységeket időben összehangolni.

\section{Időbeosztás}

A fent bemutatott tevékenységek elemzése nyújtia számunkra a kiindulópontot, azt a napi struktúrát, amely szövetébe ágyazódik az idôfelhasználás, idôbeosztás kezelése. Ha ezen tevékenységeket úgyszólván lefejtjük a struktúráról, láthatóvá válik a mögötte meghúzódó időszemlélet (mely, tegyük hozzá, visszahatásként alakítja is a tevékenységi struktúrát). Tehát ahhoz, hogy kontrollálni tudjuk a kialakult tevékenységeinket, rendelkeznünk kell egyszersmind olyan időkezelési „képességgel”, mely által e tevékenységi struktúra hatékonyan müködtethető, az egyes tevékenységek szinkronba hozhatók. A kétdés ezek után az, hogy az időkezelés és a tevékenységi struktúra milyen idői viszonyban vannak egymással, azaz melyik elổzi meg idốben a másikat. Erre a kérdésre azonban csak további kutatások adhatnak releváns választ.

A tevékenységi struktúrák mögött ideáltipikusan két időkezelési attitủd/idôszzemlélet húzódik meg, mely az interjúkból jól kitapintható.

Az egyik beállitódás jellemzöje, hogy a struktúrát alkotó tevékenységek egy idốtengelyre fưzhetők fel, így az egyes tevékenységek egymást követően alkotnak láncot. A másik ideáltipikus esetben nem egy idôtengely észlelhetô, hanem az egyes tevékenységek mind külön-külön időtengelyt alkotnak. Ezek az idổtengelyek (tevékenységek) egymás mellett léteznek, így alkotva egységes egészet.
A kétféle attitüd merôben más időfelfogást kíván meg, avagy alakít ki. Megfigyelhető, hogy az első esetben, amikor a tevékenységek egy időtengelyen helyezkednek el, az egyes tevékenységek csak úgy „fejlődhetnek” az időben, ha a többi tevékenység valamelyikét, vagy mindegyiket bizonyos korlátozások alá vesszük. A gyakorlatban ez annyit jelent, ha valaki több idổt szeretne barátaival tölteni, csak úgy kivitelezhetô, ha valamely más tevékenység(ek)re szánt időből vesz el. Ennél fogva a tevékenységek köre, vagy az egyes tevékenységek végzésére szánt idổ nem bổvithető csak a már említett egyetlen idôtengely terjedelmében.

Az utóbbi esetben azonban, mikor a valóságos idô (értsd: órával mérhetổ idô) több időtengelyből tevôdik össze, a különbözổ tevékenységek úgy szerveződnek meg, hogy azok idôben nincsenek egymásra (legalábbis szubjektív éttelemben) hatással. Ebben az esetben az alanyok arról számolnak be, hogy a tevékenységstruktúra minden elemére megfelelő és elegendổ idő áll rendelkezésre, az idő érzékelése nem a tevékenységstruktúrához viszonyítva, hanem az egyes idổtengelyeken belül nyer értelmet.

Ezen két bemutatott beállítódás látszólag kétféle tevékenységstruktúrát feltételez, illetve eredményez. Az utóbbi attitűddel azon egyének jellemezhetôk, akik napjait, idejét több rendszeres tevékenység „tördeli” szét. Ők azok, akik tudatosan alakítják és szervezik idejüket, hogy a végesnek tủnő idő kontrollálhatóvá, kezelhetôvé váljék.

„Néba úgy gondolom, bogy jól be tudom osz̨tani ą idôm, néba meg úgy, hogy nem. Elég nebéz úgy beosztani az idömet, hogy minden fontos dologra maradjon elég idôm. Igazából megpróbálok mindent rangsorolni, bogy mi a legfontosabb és mi ér még rá." 17 éves lány -

Idôbeosztásuk kialakított. gyakorlat következménye, ritkábban számolnak be arról, hogy elvesztették ,hatalmukat” az idő felett. Itt nem arról van szó, hogy ezek az interjúalanyok nem panaszkodnak arról, hogy vannak olyan tevékenységek, melyekre szeretnének több időt szánni, vagy nem érzik az idổ szorítását, pusztán artól, hogy időkezelésük sokkal tudatosabb.

„Mostanában szoktam írni egy kis cetlire, bogy miböl mennyit kell tanulnom, mi a fontosabb, miböl irok dolgozatot, arra mennyit kéne készülnöm, és akkor próbálom zigy beosztani az idömet, hogy mindegyikere jusson több ido." 16 éves lány -

Megfigyelhetỗ az is, ha ezek az alanyok időbeosztásukkal kapcsolatos elégedetlenségüket fejezik ki, mindenképpen tudatosan törekednek arra, hogy időbeosztásuk hatékonyabb legyen. 


\section{Következtetés}

A másik ideáltípus az elổzổtôl eltétő attitüdinális jellemzőkkel írható le. Ebben az esetben az egyénekben nem alakult ki az idő tudatos kezelése, vagy ha képesek is valamilyen mértékben kontrollálni az idổt, csak kisszámú tevékenység esetén képesek erre. Elbeszélésük több esetben arról tanúskodik, hogy „kifolyik kezükből az idô", ha törekszenek idôbeosztásuk racionalizálására, nem a struktúra egészére van hatással, csak a struktúra egyes elemeiben valósul az meg. Ennek nem mond ellent az sem, hogy esetenként ezek az interjúalanyok határozottan kijelentik, hogy mindenre jut elég idejük, soha nem maradnak el semmivel, mindent elvégeznek a megfelelổ idő̉ben. Természetes, hogy a nap 24 óráában minden tevékenység helyet kap a neki megfelelố időintervallummal, ha a „táérổidö” tetemes mennyiségû́.

Az interjúkból kiviláglik az is, hogy a határozott, konkrét tervekkel rendelkezỏ egyének tudatosan alakítják idejüket, időbeosztásukat, mig a kidolgozatlan jövôképpel bírók jóval kisebb tudatossággal tendezik jelen idejüket. Ha tevékenységekre lebontva vizsgáljuk meg ezen kijelentés érvényességét, már jóval színesebb képet kapunk. Érdemes ugyanis megvizsgálni azt, hogy az egyes tevékenységi körökre milyen időszemlélet jellemzô, tevékenységi körönként menynyire kidolgozott a jövőkép. Azt látjuk ugyanis, hogy az egyes tevékenységi körökre más-más időszemlélet jellemző.

Az interjúelemzés rávilágít arra, hogy a kérdezettek mentális struktúrájában a különböző tevékenységek különbözổ pozíciókat foglalnak el. Egyértelmũen kiderül, hogy az interjúalanyok nem globálisan gondolkoznak önmagukról és az általuk végzett tevékenységekről, hanem ezeket részekre bontják. Az egyes részek pedig különbözõ szerepeket takarnak. Az interjúalanyok általánosságban kétféle szereptipusról beszéltek: említettek egyrészt olyan szerepeket, melyek a jelenhez kötődnek, másrészt olyanokat, melyek csak a jövôben realizálódnak, ugyanakkor szorosan kapcsolódnak a jelenhez kötődô szerepekhez (pl. a jelenlegi tanulói szerepben jövőorientáltnak kell lenni ahhoz, hogy a jövőbeni egyetemi hallgatói szerep megvalósulhasson, melyben szintén fontos a jövőorientáció a még későbbi munkavállalói szerep megvalósításához). Már önmagában ez a kapcsolat is feltételezi nemcsak a jelenbeli szerepek egymásra hatását, de a jövőbeni szerepek visszaható hatását is. Ahogyan összekapcsolódik tevékenység és szerep, úgy fejti ki hatását a tevékenységekre jellemzô idôszemlélet a szerepre jellemzố idôfelfogásra/idỏorientációra. Ez az állítás egy olyan plurális szemlélet megalkotásához vezet(het), mely segitségével ámyaltabb képet kaphatunk az ifjúság időfelfogásáról, időképérôl, időhorizontjáról.
$\mathrm{Az}$ interjúelemzés segitségével megállapítottam, hogy az interjúalanyok ún. tevékenységstruktúrában gondolkodnak, az egyes tevékenységek azonban különbözô, az interjúalanyok által „felvett” szerepeket takarnak. Láthatóvá vált az is, hogy az egyes tevékenységek bizonyos esetben külön idötengelyekre helyezôdtek. Ebből pedig levonhatjuk azt a következtetést, hogy minden szerep bizonyos idővonatkozással jellemezhetổ. Minden szerep rendelkezik egyfajta időhorizonttal, azonban az egyes szerepek időbeli kiterjedtsége változó. Feltevésünk szerint az egyes szerepek nem csak a szerepküldốk elvátásainak mentén, valamint a szerepekhez tartozó értékek mentén kerülhetnek konfliktusba, hanem a szerepekhez tartozó idődimenzió mentén is. Ebben az esetben természetesen feltételezzük, hogy a szerepkomplexumba tartozó szerepek egy időben is fennállhatnak, a szerepek között sajátos interferencia van. Elgondolásunk szerint a szerepek (a szerepekhez tartozó viselkedési minták) még akkor is hatnak egymásra, ha a szerepek idổben távoliak egymástól. Sok esetben megfigyelhetô, hogy egy jövőbeni szerep befolyásolja egy jelenbeli szerep alakulását. A jövőbeni szerep (cél) elérése motiválttá, jövõorientálttá teszi a szereptulajdonost jelen szerepében.

$\mathrm{Az}$ interjúalanyok által említett szerepek vizsgálata támutat arra, hogy az egyes szerepekben az alanyok milyen idôszemlélettel rendelkeznek, adott szerepükben jelenre illetve jövốte orientáltak-e. Felvetổik továbbá az a kérdés, hogy az egyes szerepekte jellemző időhorizontok hogyan alkotnak egységes egészet, az idóképet tekintve milyen az egyes szerepek egymásra hatása (egyáltalán létezik-e ilyen hatás). Továbbá az egyes szerepekre jellemző időképek egymásra hatása milyen következményekkel jár (gondoljunk itt arra, mikor valaki csak úgy tud idốt szakítani a barátaira, ha a tanulásta szánt idổt csökkenti stb.). A kérdés tehát, hogy az egyes szerepekhez kapcsolódó időképek hogyan szinkronizálhatók.

További kérdésként merül fel, hogy mely szerep és hozzá tartozó időorientácó válik uralkodóvá. Kutatások mutatnak rá, hogy a szerepkomplexum azon eleme lesz uralkodó, mely szereppel a leginkább azonosulni képes az egyén. Nem tudjuk azonban, hogy az idô tekintetében hogyan működik ez mechanizmus. Nem tudjuk azt sem, hogy az egyes szerepekben milyen időori entációk uralkodnak. Végsỏ kérdésként merül fel, hogy a szerepkomplexumma együttjár-e valamiféle időkomplexum, idôkészlet. Sokszor elhangzik a bírálat, hogy a mai fiatalok csak a mának élnek, jelenre orientáltak, mely mögött sok esetben értékelés is meghúzódik. A gondolatfolyamunk mentén születổ kutatások éppen abba az irányba hathatnak, hogy ámyalja az egy-egy társadalmi csoportról eddig alkotott sematikus képet. 
Kasser, Tim (2006): Idö és fogyasztás. Internet: http://tudatosvasarlo.hu/cikkek/498 (letöltve: 2009.09.23.)

Kucsera Csaba (2008): Megalapozott elmélet: egy módszertan fejlődéstörténete. Szociológiai Szemle 17(3): $92-108$.

Meleg Csilla (2006): Aq iskola idöarcai. Pécs: Dialóg Campus.

Tahin Tamás - Jeges Sára - Lampek Kinga (2000): Iskolai végzettség és egészségi allapot. Demográfia 42(1): 70-93

Török Katalin (2006a): A társadalom idöbeosztásának kiszoloáltatott egvén - beszélgetés Dr. Vajda Z zsanna pszichológussal. Internet: htpp://tudatosvasarlo. hu/cikkek/396 (letöltve: 2009.09.23.)

Török Katalin (2006b): Idố és fogyasztás - beszélgetés Vörös Miklós sqociológus- kultúrantropalógussal Internet: http://tudatosvasarlo.hu/cikkek/400 (letöltve: 2009.09.23.)

\section{Jegyzetek}

${ }^{1}$ Az interjúkat a PTE BTK pedagógia szakos hallgatói készitették a Bevezetés a pedagógiai kutatások módszereibe c. kurzus keretén belül.

\section{A cigányság jelene és jövőképe - egy kutatás tükrében}

A mai magyar társadalom legnagyobb és a diszkrimináció által leginkább Aveszélyeztetett csoportja a cigányság. Pontos adatok nehezen adhatók róluk, mivel közvetlen rákérdezés útján aligha lehet megállapítani, hogy ki cigány és ki nem. Bizonyos becslések szerint 1971-ben 320 ezer, 1994-ben pedig már 434 ezer roma élt hazánkban (Kemény - Janky - Lengyel 2004). Az említett adatokkal azonban ellentétes a 2001-es népszámlálás eredménye, mely szerint lélekszámuk 190 ezerre tehető ${ }^{1}$. Többségük az észak-magyarországi és az északalföldi térségben él, ahol a valamilyen kisebbséghez tartozók 90\%-a romának vallja magát. Magas az arányuk a dél-dunántúli régióban is, föleg Somogy megyében (9 440 fố) és Baranya megyében (8 852 fô), azonban Szabolcs-SzatmárBereg megyéhez képest jóval kevesebb roma él ezekben a térségben ${ }^{2}$. $\mathrm{Ha} \mathrm{Bara}-$ nyát külön kiemeljük, elmondható az adatok alapján, hogy az itt élổ 8552 fó cigány kisebbséghez tartozó közül 5591 fỏ községekben, 2961 fổ pedig városokban élt 2001-ben.

Összességében kijelenthetõ, hogy a cigány népesség elszórtan, kisebbnagyobb csoportokban az ország minden településen megtalálható. 'Többnyire integrálódott a magyar társadalomba, de rendelkezik nyelvi, kulturális, antropológiai sajátosságokkal is. Etnikai dimenzióik mellett szociális problémáik, lakásviszonyaik, iskolázottsági mutatóik, munkaerőpiaci helyzetük reménytelensége jellemzi öket. Mindezek miatt is a velük szembeni elöítéletek nagyon erősek.

\section{A kutatás helyszinérōl, Komlóról}

Komló népességének alakulására és összetételére meghatározó jelentőségủ volt a bányászat fejlődése. Az iparszenỉ széntermelés növekedésével egyre jelentôsebb mennyiségư munkaerổre volt szükség. A bevándorlás két nagy szakasza közül a várossá nyilvánítást követõ időszak volt a jelentôsebb. A népesség nemcsak számszerüleg, de összetételében is jelentôsen átalakult. Az '50-es években elôször fôleg férfiak jöttek a városba, akik az építkezéseken, a bányában, vagy egyéb területen találtak munkát és csak késôbb, a helyi viszonyokat megszokva, nerncsak az ország szinte minden részéböl, de a határokon túlról is érkeztek betelepülôk. Egy a '60-as években készült statisztika szerint a magyarok mellett jelentôs számban éltek Komlón németek, cigányok, románok, horvátok, illetve kisebb számban jelen voltak a szlovák, a szerb és más közelebbról meg nem hatátozott nemzetiségek képviselöi is (Komló város bonlapja). A komlói cigánysággal kapcsolatos 2001-es adatok az 1. táblázatban láthatóak: 


\begin{tabular}{|c|c|c|c|c|}
\hline \multirow{3}{*}{$\begin{array}{l}\text { Népesség } \\
\text { összesen }\end{array}$} & \multicolumn{4}{|c|}{ Ebböl a cigány (roma, beás, romani) } \\
\hline & $\begin{array}{l}\text { nemzetiséghez } \\
\text { tartozók }\end{array}$ & $\begin{array}{l}\text { kulturális érté- } \\
\text { kekhez, hagyo- } \\
\text { mányokhoz kö- } \\
\text { tôdô }\end{array}$ & anyanyelvúek & $\begin{array}{c}\text { nyelvet } \\
\text { családi, } \\
\text { baráti } \\
\text { körben } \\
\text { használók } \\
\end{array}$ \\
\hline & \multicolumn{4}{|c|}{ sqáma } \\
\hline 27081 & 419 & 406 & 319 & 279 \\
\hline
\end{tabular}
gében - bár szüleiknél magasabb - alacsony iskolázottságú emberekkel fogunk találkozni. Azt feltételeztük, hogy nagyrészt munkanélküliek lesznek, akik jövốjüket ebből fakadóan kilátástalannak látják. Azonban hipotézisünk szerint azok, akik felismerik egyéni felelősségvállalásukat, optimistábban tekintenek a jövôbe, az egyéni felelôsséget pedig a tanuláshoz, munkához való hozzáállás befolyásolhatja.

\section{Kutatási eredményeink}

A mintába 90 fô, 51 fétfi és 39 nỏ került be. Korosztály szerint igyekeztünk középkorúakat, tehát 30 és 40 év közöttieket megkérdezni, de végül 2730 év alatti, 3431 és 40 év közötti és 2941 év feletti személy válaszolt a kérdéseink$\mathrm{re}^{5}$. tekintik a cigány nyelv valamelyikét ${ }^{3}$.

A cigány anyanyelvüek vagy cigány nyelvet beszélök alá sorolt népességszámok mát csak azért is megtévesztôk, mert köztudott, hogy Baranyában elsôsorban beás cigányok élnek, akik archaikus román nyelvet beszélnek. A mintegy 50-60 ezernyi magyarországi (dél-dunántúli) beás cigány hozzávetőleg 1/3-a él Baranyában. E kb. 20 ezerhez azonban még több ezer lovári (cigányul beszélő oláhcigány) is hozzászámolható az 1990-es adatok szerint. A beások nagy része is ma már csak magyarul beszél, körülbelül fele--kétharmada. Ha a területi elhelyezkedésüket vizsgáljuk, elmondható, hogy a legelmaradottabb, leginkább lepusztultabb várostészekben laknak, nagyrész panelekben, szoba-konyhás komfort nélküli szükséglakásokban és még mindig létező nyomortelepeken.

\section{A kutatásról}

Mint korábban említettem, nagyon nehéz pontos adatokkal szolgálni a cigányságról, éppen ezért érdemes több helyi kutatást végezni, melyek segitségével feltétképezhetővé válik a hazai cigányság helyzete. A Pécsi Tudományegyetem Bölcsészettudományi Karának szociológia és társadalmi tanulmányok szakos hallgatói a Szociológia Tanszék segítségével végzett egy kutatást Komlón 2009. mátcius végén és április elején, melynek célja a komlói cigányság jelenlegi életkörülményeinek és jövőbeli kilátásainak megismerése volt. A kutatás interjús módszerrel folyt: összesen 90, félig strukturált interjút készítettünk ${ }^{4}$. Helyszínül Komló cigányok által sû́rún lakott utcái szolgáltak, ahol személyesen az otthonukban kerestük fel az interjúalanyainkat. A válaszadók felkeresésében és a helyszínek kiválasztásában nagy segítségünkre volt a helyi Kisebbségi Önkormányzat, amelynek tagjai segítőket biztosítottak a számunkra. Ôk voltak azok, akik elkísértek minket kutatásunk helyszineire, valamint segitettek bennünket interjúalanyaink felkeresésében is.

Az interjúkérdések alapvetốen három nagy kérdésblokkra oszthatók: múltra, jelenre és jövôre. Azonban, mivel a kérdések több témát is boncolgattak, az eredmények ismertetését a család, iskolai és foglalkozási attitũdök, valamint az elégedettség témakörök szerint ismertetetem.

Csalad

A cigány családok átlagos nagysága köztudottan magasabb, mint az országos átlag. Egy 2003-as országos vizsgálat is alátámasztja ezt az állítást, mely szerint a cigányok körében az átlagos családlétszám 4,64 fö, míg az országos átlag 2,57 (Kemény - Janky - Lengyel, 2004). Ennek a magas számnak több oka is lehet: egyrészrôl a cigányok körében gyakran előfordul, hogy több család osztozik egy háztartáson, másrészrôl az adatok magasabb gyermekszámot is tükröznek.

A komlói adatok azt mutatják, hogy a legtöbben vagy ketten (leginkább párjukkal, gyermekükkel), vagy négyen (fõleg két gyerekkel, párjukkal vagy három gyerekkel egyedül) élnek egy háztartásban Az átlagos háztartás nagyság 3,59 fố, azaz átlagosan, körülbelül 4-en élnek egy családban a vizsgálatba bekerült komlói cigányok körében. Az adatok arra engednek következtetni, hogy egyre ritkább a magas gyermekszámú háztartás azaz, egyre többen gondolnak a jövôre, így kevesebb gyermeket vállalnak ${ }^{6}$.

$\mathrm{A} z$ interjúkból kiderült, hogy a cigány nemzetiségũ emberek körében nagyon fontos szerepet tölt be a család. Ennek ellenére a többség nem tervez gyermeket. Az ok mindenhol ugyan az:

„Egyelôre ilyen gazdasági belyzetben nem szeretnék gyereket... Normális ember azt csinálja, bogy megalapozza az egzisztenciát tanul és utána vállal gyermeket."

(30 éves férfi) 
Igyekeznek e szempontok szerint nevelni a gyermekeiket, hiszen a kérdezettek többsége úgy vélte, gyermeke jövôje rajta, szülőn is múlik.

„Hát rajtam biztos, bogy nagyon sokban. Én, én inkább úgy kezdeném, bogy rajtam nagyon sole múlike, hogy én bogy állok ezekbez a dolgok hoz, és hogy vagyok képes ốket, ugye patronálni abboz, bogy tudjanak menni tanulni."

$$
\text { (37 éves nô) }
$$

A mintába kerültek többsége egyetértett abban, hogy minden körülmény ellenéte a gyermekek legfontosabb feladata a tanulás. Mindez arra enged következtetni, hogy kezdik felismerni, hogy a tanulás, az iskola lehet az az eszköz, amely által gyermekeik kiemelkedhetnek, szüleikénél magasabb életszínvonalon élhetnek.

„A gyerekelenek? Ismételni fogom önmagamat. Tanulni, tanulni, tanulni! És ba ez megvan, akkor szerintem olyan nagy probléma nem lehet."

(39 éves férfi)

\section{Iskolázottság}

Kutatások bizonyitják, hogy a cigány emberek többsége alacsony iskolai végzettséggel, többségében 8 általánossal rendelkezik. Varga Aranka (2007) egy konferencia-elỏadásából kiderül, hogy bár a cigányság iskolázottsági szintje jelentôsen változott 1971 és 2003 között, azonban a cigány és nem cigány népesség közötti távolság növekedésének trendje megmaradt. A kilencvenes évek jellemzôje, hogy azz általános iskolát 14 éves korban a teljes népesség $81 \%$-a, a cigányok 31\%-a végezte el. 15 éves korban a teljes népesség esetében ez az adat $90 \%$, a cigányok esetében $44 \%$. 16 éves korra szinte a teljes népesség ( $96 \%$ ) megszerzi az alapfokú végzettséget, a cigány fiatalok esetén azonban ez az adat csak $63 \%$. A háttérben álló okok között a késôi iskolakezdés, a magas bukásarány áll, a következmények pedig a középfokon való elôrehaladás esélycsökkenését jelentik.

A komlói eredmények azt mutatták, hogy a kérdezettek több mint fele nyolc általánossal rendelkezik. A többségnek azonban van mellette egy vagy akár több oklevele is különbözô tanfolyamokról, melyeket mát felnôtt fejjel végeztek el. Így a nők közül legtöbben varrónổi, a férfiak közül pedig parkgondozói és kõmüves-segédi végzettséget szeteztek. Azonban ezekkel a végzettségekkel sem tudnak elhelyezkedni. ${ }^{7}$ Emellett többen emlitették azt, hogy az általános iskola elvégzése után elkezdték a szakmunkásképzốt, de abbahagyták. Ennek okára több interiúalany is rámutatott:
"Aztán... elkerültem... be aq Angster Józsefbe, aq 500-asba, azt ott én befejeztem, tizedikbe'... nagyon sokat buliztam... körités volt bozzá kemény... Pénz kellett... Aztán... megláttam mindenféle dologba' a könnyü pénzszerzési lebetôséget. Aztán a nyakánál fogtam... Aztán... Eq ment, ment, ment, ment..."

(23 éves férfi)

„Elmentem sima nyolcba, tudod, aztán tudod elmentem az ipariba, de otthagytam. Fél év után, ąt kész... Talán ott voltak a gyerekek a parkba, ąt elmentem, össze-vissza mászkáltam, szökedöstem, meg ennyi."

$$
\text { (31 éves férfi) }
$$

Az elôzzỏ két idézet alapján elmondható, hogy a cigány férfiak esetében a kortárscsoportok, valamint a pénzszerzés játszotta a legfontosabb szerepet abban, hogy abbahagyták az iskolát. Valószínũleg a szabadság és az önálló élet vágya hajtotta őket, amikor így döntöttek. A nők esetében teljesen más indokok vezettek a tanulmányaik korai befejezéséhez:

„8 általános, meg egyet elkezdtem a sqakközépböl... (miért hagyta abba?) Hát magánélet miatt. Már nem a tanuláson järt az eszem."

(44 éves nô)

„15 éves múlottam, amikor teberbe estem, meg kelletett sqakítani a tanulmányaimat, és most tavaly... tavaly tettem le itt a Dankó Pista közösségi házban a betet-nyolcat."

(35 éves nõ)

Ahogy az elổzỏ idézetek mutatják, a nők esetében a korai teherbeesés miatt kellett idổ elôtt abbahagyniuk az iskolát. Jóllehet, a statisztikai adatok szerint hazánkban a '80-as évek óta a felére csökkent a 20 éves kor alatti anyaság, azonban bizonyos társadalmi csoportokban, például a cigányok körében még mindig magas azon fiatal nők száma, akik túl korán vállalnak gyereket. Ennek oka több minden lehet. Gyukits György (2003) kutatásai szerint - mely kutatásokat az egyik budapesti szegénynegyedben végezte - a fiatal lányok arra használják fel születendő gyermeküket, hogy a családi kötnyezetből kiszakadhassanak, valamint hogy a felnôtté válás útjára léphessenek. Ha ezt az okot elfogadjuk, akkor kijelenthető, hogy a cigány férfiakat és nőket azonos okok vezérlik az iskola korai abbahagyására.

Mindezek után feltehetổ a kérdés, hogy gyermekeiknek ezt a jövốt szánjáke? $\mathrm{Az}$ interjúk eredményei azt mutatják, hogy nem, hiszen fontosnak tartjajk az iskolát mint a társadalmi ranglétrán való feljebbjutás eszközét. Minden kiskorú gyermeket nevelố szülõ arról számolt be, hogy szeretné, ha gyermeke továbbtanulna, és megfelelổ szakmát szerezne. 
„... elöször järja ki a nyolcat, azt mindenféleképpen. Menjen valamit, végezze el a többi sulit, ami így fontos, legyen egy szakmája neki a kezében."

\section{(25 éves nô)}

Az interjúk során arra is rákérdeztünk, hogy a szülők milyen szakmát választanának gyermekeiknek. A válaszokból fény derült arra, hogy a mintába kerültek mely végzettségeket tartják versenyképesnek, megfelelổen jövedelmezônek ma Magyarországon. A következó ábra az eredményeket mutatja meg: ${ }^{8}$

\section{1. ábra: Az interjúalanyok által versenykképesnek tartott szakmák}

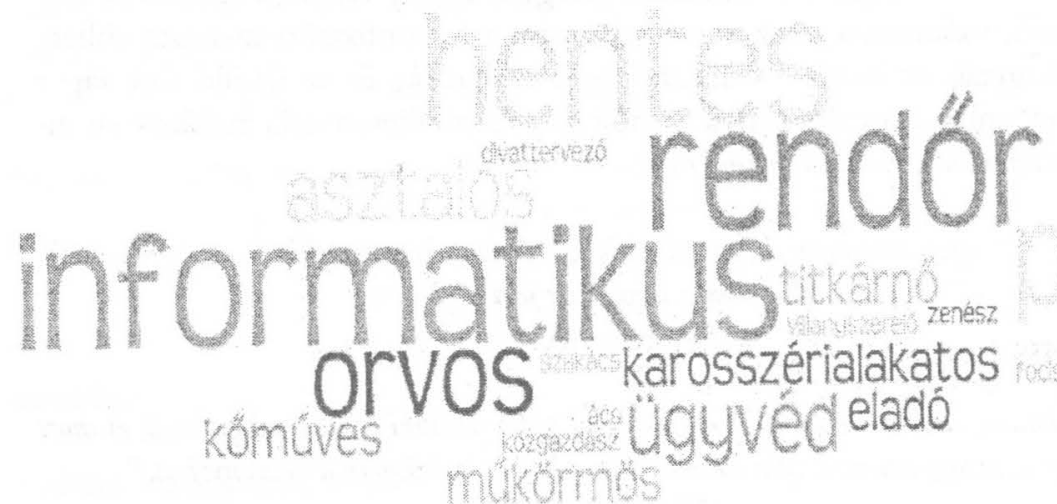

$\mathrm{Az}$ ábra kitũnően rámutat arra, hogy leginkább az informatikai, rendôri, és hentesi pályát szánnák gyermeküknek a kérdezettek. Többen említették még azt is, hogy pékként, orvosként, vagy asztalosként tudják elképzelni gyermekeiket. Úgy gondolom, a kérdésre vannak, akik reálisan, vannak, akik kevésbé reálisan, inkább az álmaik alapján válaszoltak. Óriási elórelépésnek tekinthetô azonban, hogy a szülők mindenképpen azt szeretnék, hogy gyermekeik szakmát szerezzenek.

\section{Foglalkoztatottság}

A többségében 8 általánossal rendelkezõ komlóiak álláskeresés szempontjából jelentôs hátrányban vannak, mivel végzettség nélkül manapság már nehéz elhelyezkedni. Így nem meglepó, hogy a mintába ketültek többsége munkanélküli (segély(ek)bõl él), és csak kevesen tudnak elhelyezkedni, de ők is csak rövid idốre ${ }^{9}$. Ezzel ellentétben a szülők nagy részének volt munkája. Úgy vélem, ennek legfő́bb oka, hogy a szülôk többsége a szocialista rendszerben élt és dolgozott ahol az iskolai végzettségtől függetlenül kötelező volt munkát vállalni.
Az alacsony munkavállalásnak csak egyik oka lehet az alacsony iskolai végzettség és a rendszerváltozás során bekövetkezett gazdasági változás. Véleményem szerint a munkához való hozzáallás is nagy szerepet játszik abban, hogy valaki talál-e munkát. $\mathrm{Az}$ interjúk erre is választ adnak, hiszen kiderül belôlük, hogy a komlói cigányok hogyan gondolkoznak arról, hogy mitôl függ az, hogy valaki állást kapjon.

A mintába kerültek többsége szerint a végzettség, a megfelelő szakmával való rendelkezés a legfontosabb, és közel ugyanennyien hivatkoztak az etnikai hovatartozásra. Ez utóbbival kapcsolatban többen beszámoltak arról, hogy sok munkahelyen azért utasítják el őket, mert roma származásúak.

„Ösqinte legyek?... Ha telefonon bivom fel öket, bemutatkozok, akkor azt mondják, hogy nyugodtan menjek, de ba bemegyek, rám néznek, ne haragudjon nincs felvétel."

(42 éves nő)

Az etnikai alapú megkülönböztetés - az elmondottak szerint - elöfordul a munkaadók körében Komlón. Kijelenthetô tehát, hogy itt is megjelenik az elöítélet a cigányokkal szemben, csakúgy, mint országszerte.

Többen beszámoltak arról is, hogy ahhoz, hogy munkájuk legyen, nem elég végzettséggel rendelkezni, szükség van olyan tulajdonságokra, mint az elszántság, kitattás, a folyamatos álláskeresés, azaz, hogy milyen a személy munkához való hozzáállása. Ennek kialakításában pedig fontos szerepe van a családi szocializációnak is. A gyermekek környezete jelentôs hatással bír a pályaválasztásra. Vizsgálatok bizonyítják, hogy több gyermek választja a szülei foglalkozását, ha nem is ugyanazt, de hasonló értékũ és tevékenység-sémájút (Argyle 1982). Azonban nemcsak a pályaválasztásban, hanem a munkára való szocializációban is fontos szerepet játszanak a szülök. Mivel a komlói eredmények szerint a kérdezettek többsége nem dolgozik, úgy gondolom, hogy a családi szocializáció bizonyos mechanizmusai sem mủködhettek megfelelốen, melynek következtében nagymértékưvé vált a munkanélküliség.

Mint ahogy korábban említettem, az eredmények ennek ellenére azt mutatják, hogy a szülők többségének volt munkahelye, és volt lehetôsége dolgozni, mely a szocialista rendszerben kötelezô is volt. A válaszadók elmondása szerint szüleik föleg segédmunkásként tudtak elhelyezkedni alacsony iskolai végzettségük miatt: többségében az apák bányászként, az anyák takarítónőként vagy varrónôként dolgoztak. A megkérdezett komlói cigányok közül szinte mindenki úgy gondolta, hogy a szocializmusban nem volt nehéz munkát találni, és egytôlegyig mindenki a rendszerváltás elôtti Magyarországot kívánta vissza. Mint ahogy a szülök által végzett - fóleg az apák által végzett - foglalkozások mutatják, a komlói cigányság számára a bányák jelentették a legfőbb munkalehetôséget. A következô idézet is ezt mutatja: 
„Én akkoriban bányász voltam, született bányászuáros, szinte kötelező volt, aki nem volt bányász az elszégyellhette magát. Hossqu éveken keresqtül bányász voltam."

(45 éves férfi)

A bányák bezárásával azonban rengeteg munkahely szünt meg, melynek következtében sokan maradtak munka nélkül. Úgy gondolom, hogy a mai, nagyfokú állástalanság oka az lehet, hogy a mintába kerültek többsége a szülei által mutatott mintát követve hasonló foglalkozásokat választott. Azonban az ország gazdaságilag megváltozott a rendszerváltást követỏen, átalakult a foglalkozások struktúrája, az alacsony iskolai végzettségủek ellehetetlenedtek. Véleményem szerint a hazai cigányság körében még csak kevesen fedezték fel a továbbtanulás és a munkaerôpiacon való boldogulás közti összefüggést, és még csak most kezdenek alkalmazkodni a rendszerváltozás utáni gazdasági körülményekhez.

\section{Elégedettség}

A foglalkoztatottsági mutatók kedvezõtlensége miatt szinte egyértelmü, hogy a komlói cigányok elégedetlenek a jelenlegi életkörülményeikkel. Az elégedetlenség azonban nem csak a cigányok körében magas. Egy kutatás szerint (Sági 2002) a kelet-európai országok közül Magyarországon különösen magas azoknak az atánya, akik elégedetlenek életszinvonalukkal. Ez az elégedetlenség azonban nem jellemzỏ az élet minden területére, leginkább az anyagiakkal kapcsolatos tényezőkkel és az egészségügyi állapotukkal elégedetlenek a hazai emberek.

A mintába kerültek többsége is az elégedetlenség okaként elsősorban az alacsony jövedelmet és a munkalehetỏségek hiányát emlitették. Kevesebben voltak azok, akik a politikát vagy a jelenlegi lakókörnyezetüket hibáztatták a fennálló helyzet miatt. A válaszolók többsége szerint a legnagyobb problémájuk az, hogy máról-holnapra élnek, és sok esetben, ha a közüzemi számlákat kifizetik, ennivalóra már alig marad pénzük.

„... a legalacsonyabb szinvonalon vagyunk. Tehát tényleg bogy... ügy van, hogy amire kifizetnénk mindent, akekor nem marad semmire. Így van, amikor fizetünk, akkor abban a bónapban meghúzzuk a nadrágszijat, ha nem fizetünk, akekor bónapról bónapra élünk. Tebát ez, amit kapunk, eq nagyon kevés nekünk.

$$
\text { (40 éves nó) }
$$

Fontos kiemelni, hogy az elégedettség egy nagyon szubjektiv fogalom, mely miatt az életszínvonal értékelése úgy gondolom, hogy személyiségfüggó. Véleményem szerint azoknak az interjúalanyoknak, akik elégedettségről számoltak be, 2 többiekétől eltérô a viszonyitási alapuk.
„Elégedett vagyok, én nem akarok többet. Van bol lakjak, van fedél a fejem felett, van mit ennem, velem van a fiam, most kezdek úgy lelkileg helyre jönni."

$$
\text { (41 éves nô) }
$$

"Igen, igen, sö́t néha azt mondom, hogy szégyen. Mert elmondhatom, hogy soba semmilyen kö̈zli ismerösöm nem balt meg, és egészségügyi problémánk nincsen. Olyan, amilyér, panaszkodni érdemes, olyan nincs. És én azt mondom, hogy anyagilag is. Nem azt mondom, bogy jól élünk, de elégedettek. lebetünk magunkkal. Nem fázunk, nem ázunk, viszont több mindent megengedhetünk magunknak, mint az átlag ember. Semmit nem kapunk, nem is kaptunk, mindenért megdolgozunk."

$$
\text { (40 éves nó) }
$$

Az idézetek mutatják, hogy vannak, akik azzal is elégedettek, hogy van hol lakniuk, vagy van mit enniük, vagy esetleg a családban minden rendben van. Tehát ők sem élnek sokkal jobban, mint azok a cigányok, akik elégedetlennek találták mostani helyzetüket, azonban teljesen másképp értékelik azokat a dolgokat, amikkel rendelkeznek.

Mivel a mintában az elégedetlenek voltak többségben, mindenképpen érdekes megvizsgálni, hogy ha nem érzik jól magukat a jelenlegi életszínvonalukon, akkor mit tesznek, és mit kellene tenni azért, hogy ez megváltozzon.

A kérdezettek többsége szerint több munkalehetőségre lenne szükség ahhoz, hogy elégedettnek mondhassák magukat. Sokan említették azt is, hogy a környékről való elköltözés vagy egy saját lakás (többségében önkormányzati lakásokban laknak) jelentene számukra megoldást. De voltak olyanok, akik egy autótól, magasabb bérektől és alacsonyabb áraktól, valamint a hiteltartozások megszủnésétől lennének elégedettek. Az életük jobbá válásának kapcsán a véleményeket a következỏ idézet jellemzi leginkább:

„....nem lennék gazdag, ment nem kell az a sok pénz, kicsit jobb legyen, hogy mindent... ne ügy legyen, bogy egy bónapban egyszer kapjunk pénzt, hanem be tudjuk osztani is. Mer azért a kevés... kap a párom is, hát aq... nem sok, pénzt... nevet... elmegy a fele a fizetésre." (29 éves nõ)

Az emlitett igények egy része olyan, amelynek alakulásáról nem igazán ôk dön tenek, de vannak köztük olyanok is, melyekkel kapcsolatban csak ök érhetnek el változást. Ezért is fontos rámutatni arra, hogy kitől várják a helyzet megváltozását.

Ez a kérdés jelentôsen megosztotta a mintába került egyéneket, mivel közel ugyanannyian voltak azok, akik szerint saját maguk és akik szerint a kormány, a politika tehet arról, hogy hogyan alakul az életük. Azok, akik úgy vélekedtek, hogy egyedül a kormány, a politikai vezetök képesek a helyzetükön változtatni, azt hangsúlyozták, hogy ha ők nem biztosítanak munkalehetôségeket, vagy 
bizonyos szociális törvényekkel nem segitik a szegényebb rétegek elhelyezkedését, akkor ök maguk tehetetlenek.

„Hát az országon. Van munkahely? Nincs munkabely, hova menjen? Most biába, figyely, akármit is tanulok ki, na most nekem a szakmám kömüves, bogy ba nem tudok abba a belyzetbe dolgozni, most biába."

$$
\text { (40 éves férfi) }
$$

Akik viszont úgy vélekedtek, hogy saját magukon múlik, többségében azzal érveltek, hogy ha nem járnak folyamatosan munkát keresni, akkor sohasem lesz esélyük elhelyezkedni.

„Én úgy érzem, hogy igen, rajtam. Szóval rajtam is. Páromon is. Lesznek nagyon nebéz, nagyon rossz idöszakok, tudom, aq évek során, de mindketten ott vagyunk, oda állunk, és mindketten kölcsönösen kivesszülk, a részünket, akkor megoldjuk a feladatot, akkor nincs olyan akadály, amit nem bímánk legyózni. Akár anyagi, akár lelki, akár más probléma. Bármi adódhat."

(29 éves férfi)

Az így gondolkozók többség úgy látta, hogy az egyetlen lehetőség a folyamatos munkakeresés (a kérdésre válaszolók több mint fele így nyilatkozott), míg voltak, akik úgy vélekedtek, hogy az egyetlen lehetőség a jelenlegi lakókömyezetből való kikerülés lenne, és ennek eléréséért tesznek meg mindent. Közel ugyanenynyien számoltak be arról, hogy Magyarországon nem találnak megfelelố munkahelyet, és csak a külföldi munkavállalás segítheti ki őket a jelenlegi reménytelen helyzetükből. Kevesen emlitették azt, hogy spórolnak vagy esetleg továbbképzik magukat.

\section{Következtetések}

A cigányokkal kapcsolatos eltérõ adatok is azt mutatják, mennyire nehéz pontos népességbeli adatokat kapnunk errổ a kisebbségrôl. Ezért fontosak az apróbb kutatások, melyek rávilágitanak egy-egy település cigány közösségének jellemzôire. A Pécsett tanuló, szoriológia és társadalmi tanulmányos egyetemi diákok komlói kutatása, úgy vélem, siketesen feltétképezte az ottani cigányság föbb családi, iskolai, foglalkoztatottsági, elégedettségi mutatóit, valamint e témakörök mentén jövőbeli kilátásaikat is.

Az eredményekből kiderült, hogy a komlóiak körében a család fontos szerepet tölt be. Az országos kutatásokkal szemben a kérdezettek körében az alacsony gyermekszámmal rendelkezỏ háztartások voltak többségben. Ezt a jelenlegi gazdasági helyzettel, egyre romló anyagi körülményeikkel magyarázták. Elismerték azt, hogy a gyermekek számára a legfontosabb feladat a tanulás, melynek hátterét a szülöknek kell biztosítani. Ez azonban komoly feladat, hi- szen a szülők többsége alacsony iskolai végzettsége miatt a legtöbb munkahelytôl kiszorul.

A kérdezettek iskolai adatai alapján elmondható, hogy több mint felük 8 általánost végzett, és egy olyan személy sem került be a mintába, aki felsőfokú végzettséggel rendelkezett volna. Szüleik adatai ennél elkeserítőbbek: a szülők többsége még az általános iskolát sem végezte el. Így elmondható, hogy valamelyest javultak az iskolázottsági mutatók, melyeket alátámaszt az is, hogy a kérdezettek fiatalkorú gyermekeinek többsége még tanul, és mindegyik legalább egy szakmunkásképző elvégzéséte ösztönzi gyermekét. A kutatások azt mutatják, hogy szegénység és munkanélküliség vár azok többségére, akik csupán 8 általánost vagy kevesebbet végeznek el, így a cigányság társadalmi helyzetének megváltozásához az kellene, hogy a fiatalok többsége középfokú végzettséget szerezzen. Fontos lenne, hogy a cigányság felfedezze a tanulásban rejlô lehetőségeket. Ehhez persze szükség lenne arra, hogy az oktatási rendszer figyelembe vegye e személyek szocializációs különbségeit, és ezek alapján dolgozza ki az oktatás irányelveit, módszereit.

Mint ahogy fentebb említettem, az alacsony iskolai végzettségből adódóan a cigányok többsége állástalan országos szinten és Komlón is. A mintába kerültek kétharmada nem dolgozik, és több mint egynegyedük szociális segélyből tartja el a családját, szemben szüleikével, ahol közel $90 \%$-os volt a foglalkoztatottság. Ennek okai többfélék lehetnek, véleményem szerint a legnagyobb probléma, hogy a szocialista rendszer által preferált foglalkozásokat sajátították el, melyek a rendszerváltozás után elértéktelenedtek, valamint a másfajta gazdasági berendezkedés átvétele a cigányok körében még nem történt meg. Erre mutat tá a következô idézet is:

„Mert nálunk volt egy szokás, egy talán egy bagyomány, bogy mi ugye abogy kijärtuk a 8 általánost, akekor csatlakoztunk, az ösök, sqakmájához. Mentünk ki mi is dolgozni rétekre, erdökbe, bárbova, abol ök dolgoztak."

(39 éves férfi)

A fent említett adatok után nem meglepô, hogy többségében elégedetlennek bizonyultak jelenlegi élethelyzetükkel kapcsolatban a mintába került személyek, a munkalehetôségek hiányával, az állami politikával indokolták nehéz körülményeiket. Voltak olyanok is, akik felismerték, hogy nemcsak az államon múlik a helyzetük, hanem ők maguk is tudnak tenni azért, hogy megváltozzon a helyzetük $^{10}$. E személyek optimistábban tekintenek a jövőbe. Így kijelenthetổ, hogy a komlói cigányság jövổképét nagyban befolyásolja felelösségvállalásuk, amit viszont a munkához, tanuláshoz való hozzáállással van szoros kapcsolatban. Úgy gondolom, ezért lenne fontos, hogy az egyéni felelôsségvállalás elengedhetetlenségét széleskörüen felismerjék.

Véleményem és az eredmények szerint a rendszerváltozás utáni, gazdaságban végbement változások a hazai cigány népességet jelentősebben érintették, 
mint a nem cigányokat. Komlón ez még eröteljesebben megjelent, hiszen itt a legtöbb munkalehetôséget számukra a bányák biztositották, melyeket a megváltozott piaci körülményekhez igazodva sorra bezártak. Igy összességében kijelenthetô, hogy a cigányság helyzete hazánkban elkeseritố, hiszen a társadalom legszegényebb és leginkább kirekesztett csoportiát képezik. Ahhoz, hogy változás következzen be, szükség van a szocializációs minták megváltozására, minimálisra kellene csökkenniük a kirekesztổ mechanizmusoknak, és el kellene tünnie az elöitéletes gondolkodásnak. Maguknak a cigányoknak is át kellene gondolniuk a jelenlegi helyzetüket, és fel kellene ismerniük, hogy jövőjük nemcsak másokon múlhat. Azonban ez a kép - ha folytatódnak a jelenlegi tendenciák csak utópia maradhat...

\section{Irodalom}

Argyle, Michael (1982): Személyiség és munka. In Nagy Katalin (szerk.): Szocializáäcó. Szöveggrüjte mény pályaválasztással foglalkozó pedagógusok, pszichológusok számára. Budapest: OPI, 175-199.

Gyukits György (2003): Gyermekvállalás a nagyvárosi szegénynegyedben élỏ fiatalkorú roma nök körében. Szociológiai Szemle 13 (2): 59-83.

Kemény István - Janky Béla - Lengyel Gabriella (2004): A magyarországi cigányság 1971-2003. Budapest: Gondolat Kiadó

Komló város honlapja. Internet: http://www.komlo.hu (letöltve: 2009. október 16.)

Népszámlálás 2001. A nemzetiségi népesség száma településenként - cigány. Internet www.ncpszamlalas.hu/hun/kotctck/04/tabhun/tabl11/load11002.html (lctöltve: 2009. október 16.)

Sági Matild (2002): Elégedettség, jövedelmi feszültség. In Kolosi Tamás - Tóth István György Vukovich György (szerk.): Társadalmi Riport 2002. Budapest: TÁRKI, 75-92.

Varga Aranka (2007): Cigány gyerekek az oktatásban - együttmüködésre épüló inkluríviv iskola. Internet: www.btk.ptc.hu/tanszckck/romologia/dok/sal/Aranka Varga\%20-

$\% 20$ Gypsy $\% 20$ children $\% 20$ in $\% 20$ the $\% 20$ education.doc (letöltve: 2009 . október 16 )

\section{Jegyzetek}

1 Véleményem szerint ez is azt mutatja, hogy mennyire nehéz pontosan megadni a létszámukat

${ }^{2}$ Szzabolcs-Szzatmár-Bereg megyében 25612 fô vallotta magát romának 2001-ben.

${ }^{3} \mathrm{E}$ mögött valószinûleg à önazonosság megvallásától való félclcm állhat.

${ }^{4}$ Azért $a$ in interjús módszert válaštottuk, mert úgy gondoltuk, hogy exáltal mćlycbb ismerctekhe’ juthatunk akár a kérdezettel, akár a kömyezetével kapcsolatban.

${ }^{5}$ Fontos megcmlíteni, hogy interjúalanyaink etnikai hovatartozásával kapcsolatban nekünk kcllctt döntést hoznunk, igy olyan šcmélyeket kćrdeztünk meg, akiket mi romáknak gondoltunk, de az interjú alatt rákérde`tünk arra is, hogy alanyaink milyen nemzetiségünek vallják magukat.

${ }^{6}$ Eat támaštja alá az is, hogy a vizsgált családokban átlagosan kćt gycrmeket nevelnek.

${ }^{7}$ A mintába kerültek még így is iskolai vćgzcttsćg šempontjából többet „elértek” mint szüleik A\% interjúkból kiderült, hogy a szülôk többsćge a 8 általánost scm vćge»te el, és egyik alany scm számolt be arról, hogy szülei érettségivel rendelkestek volna

${ }^{8} \Lambda$ szakmák betümérete arányos az említések számával.

9 A fulvétel idején a megkćrde\%cttek közül csak minden ötödik volt foglalkoztatott.

${ }^{10}$ Ỏk kevésbé látták borúsan jövởjüket, mint àok, akik šcrint saját sorsuk alakításába nem šólhatnak bele

\section{NÉMETH A. VIOLETTA}

\section{Láthatatlan falak ámyékában Antiszegregáció Pécsett}

z 1980-as évek végén és a 90-es évek elején Kelet- és Közép-Európában A bekövetkezett társadalmi, gazdasági és politikai változások nyomán olyan folyamatok indultak meg a volt kommunista országok nagyobb városaiban, amelyek felkészületlenül érték a társadalmakat. Megindult a polarizálódás, etôteljesebbé vált a lakosság vagyoni differenciálódása. Ennek következtében a városokon belül felgyorsult a különbözỏ társadalmi és vagyoni helyzetủ csoportok térbeli elkülönülésének folyamata, megkezdődött, vagy sok helyen inkább tovább folytatódott és véglegessé vált egyes várostészek, lakóövezetek szociális és fizikai lepusztulása (Pörös 1997). Így alakultak ki a szegregált városi lakóterületek. A szegregálódó területeken élốk alapvetốen a szegényebb társadalmi téteghez tartoznak, és a szociálisan halmozottan hátrányos helyzetủek koncentrációja jóval meghaladja a város más részeire jellemzô értékeket.

A Dél-Dunántúli régió központiát, Pécs városát nézve mindez különösen jellemzô folyamat. A rendszerváltozás utáni gazdasági változások, a korábbi nagyipari üzemek, bányák bezárása elindított egy olyan folyamatot, melynek következtében nagymértékben visszaesett a foglalkoztatottak száma. Szélesebb társadalmi réteg került peremhelyzetbe

Az átalakulás vesztesévé leginkább a roma népesség vált őket érintette leginkább a munkahelyek bezárása. Az érintett egyének kiesnek a társadalom mû́ködéséből, ami kirekesztődéshez vezet. Mindezek problémát jelentenek személyes, települési és országos szinten egyatánt. Marginalizálódott helyzetben a mobilizációs csatornák beszűkülnek. Sok esetben az érintett személyek iskolázatlanok, alapvetô társadalmi, kulturális és politikai jogaikat sem tudják gyakotolni. Ezek akut kirekesztôdéshez vezetnek, mely a társadalom legszélére történổ kiszorulást eredményez.

Az 1990-es évek konszenzuális politizálása vezetett a fenntartható városfejlôdés elméletének elterjedéséhez a várospolitikában. Legfontosabb tevékenységének célkitüzése a regeneráció, mely átfogó, integrált szemléletmód és beavatkozás. Célja a vátosi problémák megoldása, a gazdasági, fizikai, társadalmi kötnyezet feltételeinek tartós javítása. Ezek közül a társadalmi kömyezet regenerációja jelenti a legnagyobb kihívást (Egedy és Kovács 2005: 12).

Az Integrált Városfejlesztési Stratégia ${ }^{1}$ ketetén belül 2008 júliusában készült el az Antiszegregációs Terv, melynek célja a telepszerũ, szegregált lakókörnye zeti népesség társadalmi, gazdasági szempontú vizsgálata, és a feltárt problémák alapján pedig olyan cselekvési programok kidolgozása, amellyel ezek a gondok 